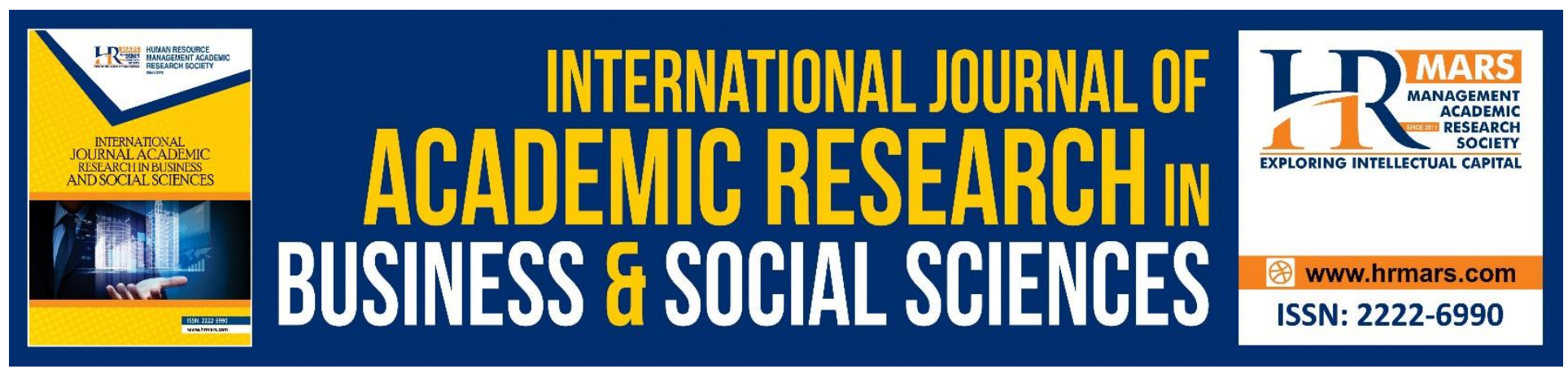

\title{
Shariah Committees' Remuneration Disclosure Transparency by Islamic banks in Malaysia
}

Syahiru Shafiai, Muhammad Rahmat Rosle

To Link this Article: http://dx.doi.org/10.6007/IJARBSS/v8-i11/5357

DOI: $10.6007 /$ IJARBSS/v8-i11/5357

Received: 19 Oct 2018, Revised: 28 Nov 2018, Accepted: 30 Nov 2018

Published Online: 02 Dec 2018

In-Text Citation: (Shafiai \& Rosle, 2018)

To Cite this Article: Shafiai, S., \& Rosle, M. R. (2018). Shariah Committees' Remuneration Disclosure Transparency by Islamic banks in Malaysia. International Journal of Academic Research in Business and Social Sciences, 8(11), 1816-1826.

Copyright: (C) 2018 The Author(s)

Published by Human Resource Management Academic Research Society (www.hrmars.com)

This article is published under the Creative Commons Attribution (CC BY 4.0) license. Anyone may reproduce, distribute, translate and create derivative works of this article (for both commercial and non-commercial purposes), subject to full attribution to the original publication and authors. The full terms of this license may be seen

at: http://creativecommons.org/licences/by/4.0/legalcode

Vol. 8, No. 11, 2018, Pg. 1816 - 1826

http://hrmars.com/index.php/pages/detail/IJARBSS

JOURNAL HOMEPAGE

Full Terms \& Conditions of access and use can be found at http://hrmars.com/index.php/pages/detail/publication-ethics 


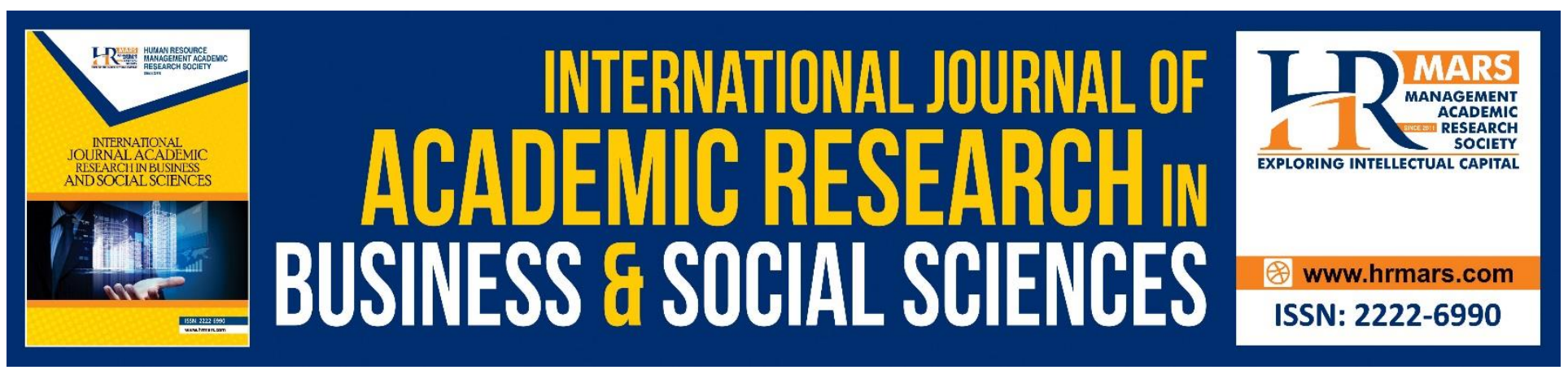

\title{
Shariah Committees' Remuneration Disclosure Transparency by Islamic banks in Malaysia
}

\author{
Syahiru Shafiai ${ }^{1}$, Muhammad Rahmat Rosle ${ }^{2}$ \\ ${ }^{1}$ Graduate Fellow, Islamic Science University of Malaysia, Malaysia \\ ${ }^{1} \mathrm{PhD}$ Candidate, International Islamic University Malaysia, Malaysia \\ ${ }^{2}$ Associate Auditor, PwC Malaysia, Malaysia
}

\begin{abstract}
This study explores the issue of Sharicah Committees' remuneration disclosure as reported by the Islamic financial institutions in the annual reports in Malaysia. Sharicah Committees are central to Islamic financial structure and they play a substantial role in the efficient functioning of the financial system. This paper also aims to provide an understanding as to whether current Sharicah Committees' remuneration disclosure practiced by the banks are able to achieve the demands of shareholders in assisting them to improve on transparency. The extent and nature of Sharicah Committees' remuneration disclosure are gathered from the content analysis of annual reports of 16 Islamic banks for the year of 2014, 2015, 2016 and 2017. To clarify the factors that could affect board decisions about the level of discretionary disclosure details concerning Sharicah Committees' remuneration. The paper discusses the need for improving transparency through sufficient, valid and pertinent disclosure of Sharicah Committees' remuneration in the annual reports by Islamic financial institutions. What is required is not necessarily only the disclosure of the total remuneration paid to the Sharicah Committee individually, but it should consist an explanation, in plain and comprehensible language, of how remuneration is used to ensure Sharicah Committees successfully delivering on the key performance indexes connected to the strategic vision of the Islamic banks. This paper also will divide to two categories of disclosure which is qualitative and quantitative disclosure. Keywords - Disclosure, Remuneration, Sharicah committee, Sharicah governance, Transparency
\end{abstract}

\section{Introduction}

Islamic banking and finance has grown globally. According to World Islamic Banking Competitiveness Report 2016 (EY, 2015), the accumulation of profit from Islamic banking industry worldwide was anticipated to achieve USD $\$ 30.3$ billion by 2020 and approximately $80 \%$ of international banking assets are based in Malaysia, Turkey, Qatar, Indonesia, United Arab Emirates (UAE) and Kingdom of Saudi Arabia (KSA). Malaysia's capabilities in the Sharicah- compliant asset management industry had developed from strength to strength. Simultaneously, Malaysia has always been an important player 
in the global Islamic financial system and also leading worldwide in the global sukuk issuance volumes and yet it would be hard to argue that its economy is heavily reliant on oil prices (GIFR, 2017). Malaysian government will continue to ensure that Malaysia will be a global leader in Islamic asset management (Hanadzlah, 2012a). As Malaysia moves progressively to be a high-income economy, 60 percent of Malaysian Gross Domestic Product (GDP) by the year 2020 will be contributed by the service sector. Hence, Malaysia's financial industry is predicted to be a crucial element in the nation's service economy with Islamic finance industry as one of Malaysia's largest competitive value propositions (Hanadzlah, 2012b).

In the Islamic banking system, Sharicah committees are central to Islamic financial structure and they play a significant role in the efficient functioning of the system besides ensuring that Malaysia's pole position in Islamic finance within the Asia countries (GIFR, 2017). The financial transactions, services or products that claim to be in compliance with Islamic standards must be assessed according to a given set of Sharicah principles. Such standards and principles are developed and advised by the Sharicah committees. In line with that, Islamic Financial Institutions (IFIs) and conventional institutions that provide Sharicah compliance financial products or services are required to have such committee by either appointing their own Sharicah committee or outsourcing this committee to private consultancies offering Sharicah advisory services (Bakar, 2016). The Sharicah committees have a tall order to support IFIs in the improvement of their products and services.

According to Shariah Governance Framework issued by Bank Negara Malaysia, (BNM-SGF, 2010), Part $1(1.2)$ :

"Bank Negara Malaysia (the Bank) places great importance in ensuring that the overall Islamic financial system operates in accordance with Shariah principles. This is to be achieved through the two-tier Shariah governance infrastructure comprising two (2) vital components, which are a centralised Shariah advisory body at the Bank and an internal Shariah Committee formed in each respective Islamic financial institution (IFI)."

Part 1 (1.4):

"The Bank has developed the Shariah governance framework for IFIs with the primary objective of enhancing the role of the board, the Shariah Committee and the management in relation to Shariah matters, including enhancing the relevant key organs having the responsibility to execute the Shariah compliance and research functions aimed at the attainment of a Shariah based operating environment."

\section{Purpose of Study}

Given the importance of Sharicah governance, this paper discovers the disclosure of Sharicah remuneration as informed by the financial institutions in the annual reports. The purpose of this study is to discuss the deficiencies in public reporting of Sharicah committee's remuneration among Islamic bank is Malaysia and the requirements of the guidelines to improve the Sharicah governance in the IFIs. This study also is to clarify the factors that could affect board decisions about the level of 
discretionary disclosure details concerning Sharicah Committees' remuneration. The paper discusses the need for improving transparency through sufficient, valid and pertinent disclosure of Sharicah Committees' remuneration in the annual reports by Islamic financial institutions. The previous research explored on 132 IFIs in 31 countries by Ahmed (2015) found that the Islamic finance world has two different standards between the International Financial Reporting Standards (IFRS) and the AAOIFI - Accounting and Auditing Organization for Islamic Financial Institutions Financial Accounting Standards Financial Accounting Standards (FAS). The study showed 60 percent IFIs do not implement a variance requirement, whereas only 38 percent use a variance for the financial reporting of Islamic financial transactions. The remaining balance of two percent IFIs did not clearly the reporting standards that they use for the financial reporting of their banks. But Harahap (2002) is much more concerned with international accounting standard practiced by conventional banking usually issues some obligatory and voluntary supply of information concerning the level of disclosure in the annual report whilst Kasim (2012) found it aims to provide discernments as to whether current Sharicah remuneration disclosure practices by Islamic banks are able to meet the requests of shareholders to support them in enlightening transparency to enhance corporate governance. The debate about Sharicah Committees' remuneration has gained fresh prominence with many arguing that this subject has been the focal point of contention by some shareholders, especially the media (Bakar, 2016).

Harahap (2002) points out the AAOIFI has set up Islamic accounting standard that comprises of slightly different type of disclosure requirements and regulations for the Islamic financial institutions. Islamic accounting can be extensively defined as a system of information that provides result of operation of institutions and make sure that the data and statistics disclosed are valid and justifiable, Sharicah compliance, and most importantly, it must be free from any incorrect corporate information. Hence, the perspectives of legitimacy theory and corporate governance structures are entreated in this paper. The scenario in Malaysia's capital market and public ownerships had made this conceptual paper off more importance for the Islamic finance industry. This research on the disclosure of remuneration on Sharicah Committee in IFIs will be of interest to policy makers and stakeholders in Malaysia and to the remuneration committee. They will be able to value the present Sharicah regulatory framework in improving the level of transparency of Sharicah Committees' remuneration of by Islamic banks in the annual reports (Bakar, 2016). This remuneration disclosure has valuerelevance to stockholders and the public interest. Although extensive research has been carried out on Shari'ah Committees' remuneration, previous study missed out on the reasons that affects IFI's decisions to voluntarily disclose the fees individually or in lump sum detail regarding Sharicah Committees' remuneration.

Along with this growth in this issue, in her analysis of the importance of transparency and disclosure (Elfeky, 2017) identifies big four accounting firms auditors gravitate to reveal more information voluntarily since a big four auditor attempts to maintain its status and supports stakeholder through superfluous disclosure. 


\section{Remuneration Disclosure}

Islamic financial institutions publish their annual report for the public as a source of information on their business achievement and performance. Hence, it helps to strengthen the transparency of the company (Bakar, 2016). From the community's perspective, the financial institutions are under pressure, and the institutions have begun to release other information including risk exposures, management policies and also risk management practices (Jizi \& Dixon, 2017; Shabbir, 1999). However, every company has their own remuneration disclosure to ensure the report depicts the relationship between the strategic objectives of the firm, the key performance indexes and the remuneration policy (Deloitte, 2016). Furthermore, the annual report should disclose both financial and non-financial performance measurement to the public including the operation of base pay, bonuses, and short and long-term incentives in link to the execution of the firm. This view is discussed by Ainley, Mashayekhi, Hicks, Rahman, \& Ravalia (2007), from their finding, Financial Services Authority (FSA) of England have been actively participated for Islamic finance expansion. The key point from the FSA's perspective is that firms can effectively show that the accountabilities of their Sharicah Committees are advisory. The variables that the FSA normally focuses on with regards to Sharicah Committee includes the reporting guidelines, governance, remuneration structure and lastly, the terms and references of the Sharicah Committee's contracts of service.

According to Financial Reporting for Islamic Banking Institutions issued by Bank Negara Malaysia, (BNM-FRIBI, 2013), Minimum Disclosure Requirements, Part 11.16

"A licensed person shall disclose CEO, Directors' and Shariah Committee members' remuneration with a breakdown of types of remunerations (e.g. salary, fees, bonus, benefits-in-kind, retirement benefits), disclosed separately for the CEO and each individual director, distinguishing between executive and non-executive directors, and Shariah Committee members."

By way of the explanation from the section, the annual report should parse the remuneration as disclosed in the financial report. What is required is not necessarily only the disclosure of the total remuneration paid to the Sharicah Committee individually, but it should consist of justification, in plain and comprehensible language, how remuneration is used to ensure that Sharicah Committees delivers on the key performance indexes connected to the strategic vision of the Islamic institutions. Similarly, Bakar (2016) found that disclosure and transparency of Sharicah professional fee are significant to get rid of all the negative perceptions on this issue.

The Financial Accounting Standards Board (FASB) and the International Accounting Standards Board (IASB) state that a key purpose of financial statements was to improve decision-making by lenders, shareholders, potential investors and other providers of capital and investment. The companies should give maximum disclosure of each individual Sharicah Committees' remuneration in the annual report of the company, providing details of base pay, meeting allowances, other remuneration, benefits-in-kind, and all other benefits. The International Integrated Reporting Framework, issued by the International Integration Reporting Council (IIRC, 2013) discussed that the integrated report by 
INTERNATIONAL JOURNAL OF ACADEMIC RESEARCH IN BUSINESS AND SOCIAL SCIENCES

Vol. 8, No. 11, Nov, 2018, E-ISSN: 2222-6990 @ 2018 HRMARS

organization sets out how the remuneration of directors is related to performance in the short, medium and long term, including how it is connected to the organisation's wealth.

\section{Legitimacy Theory}

Suchman (1995, p. 574) deliberates that "Legitimacy is a generalized perception or assumption that the actions of an entity are desirable, proper, or appropriate within some socially constructed system of norms, values, beliefs, and definitions." In this paper, legitimacy theory has the part of clarifying the organizations behaviour in fulfilling voluntary social disclosure of information in order to meet shareholder requirements. Public perceptions toward to the financial institutions undertakings are disclosed in reported in line with the requirements of industry players (Idowu, Capaldi, Zu, \& Gupta, 2013).

\section{Transparency}

Transparency is defined as "the public disclosure of reliable and timely information that enables users of that information to make an accurate assessment of a bank's financial condition and performance, business profile, risk profile and risk management" (BCBS41, 1998, p. 4). The guidelines on disclosures and financial reporting were also covered by Malaysian Islamic banking and finance ecosystem. For instance, Guidelines on Financial Reporting for Islamic Banking Institutions (BNM-GP8-i, 2012) has been reviewed by BNM to improve facilitating users of financial statements to evaluate and measure different risks profiles and characteristics. The guideline is effective from $1^{\text {st }}$ January 2014 and is estimated to boost more quality, transparency and significance of Islamic finance system (Insights, 2014). Hence, it is to make sure that the reporting standard will be in line with Malaysian Financial Reporting Standards (MFRS).

\section{Qualitative and Quantitative Disclosure}

In remuneration disclosure, there are main disclosures on remuneration that may be contained in the IFIs annual financial report statement. Banks are strongly recommended not only to disclose the basic information, but to articulate as far as possible how they remunerate their Sharicah Committees according Shariah Governance Framework for Islamic Financial Institutions, issued by Bank Negara Malaysia (BNM-SGF, 2010).

\section{Part 2 (2.6)}

"The board shall remunerate the Shariah Committee members appropriately as advised by its Remuneration Committee. Such remuneration shall reflect, and be commensurate with, the accountability, duties and responsibilities of the Shariah Committee."

The Basel Committee on Banking Supervision has issued the Pillar 3 disclosure requirements consolidated and enhanced framework (BCBSD400, 2017). This standard represents the second phase of the Committee's review of the Pillar 3 disclosure framework and builds on the revisions to the Pillar 3 disclosure published by the committee in January 2015 (BCBSD309). The current version has discussed two categories of disclosure which is qualitative and quantitative disclosure. These Pillar 3 requirements on remuneration will allow shareholders to evaluate the transparency of the 
reward practices and improve effective market discipline and the eminence of support for a risk posture and bank's policy. These requirements have been suggested to encourage useful assessments by market players of a financial institution's remuneration practices, as long as not requiring disclosure of confidential data or sensitive information.

\section{The Excessive Remuneration Debate}

Hasan (2011) is more concerned the absence of any limitation on the Sharicah committee's remuneration may lead to dangerous practices. The highest paid ten Sharicah scholars who have led board positions in IFIs around the world earn significant amounts as remuneration. In the same vein, Alnasser \& Muhammed (2012) notes that there are asserts about issues relating to Islamic scholars and Sharicah committees has been getting more. According to Jaafar \& El-Shawa (2009) the company will gain many advantages board size gets larger. This is because the directors with cross-directorship will get more networking opportunities from other companies. Jensen \& Murphy (1998) said that there should be more emphasis on how Sharicah executives are remunerated. The developing attention in executive compensation is not only restricted to academic world but also to the community (Southam \& Sapp, 2010). Hence, it would influence on corporate governance and managerial conduct in the financial industry. The academic inquiry of board compensation and public discussions surrounding executive compensation and extends outside economic theory (Baker, Jensen, \& Murphy, 1988). According to Faulkender, Kadyrzhanova, Prabhala, \& Senbet, (2010); Jensen \& Murphy (1998), the global competition for executive talents has given significance to issues of compensation which helps in recruiting and retaining these executive. It has been debated that the level of pay or salary plays an important role in attracting executive talents to an organization.

In his analysis, Ray Proctor (2006) identifies labour, land or capital are no more classified the major problems but the issue of more knowledge-based and intellectual human capital (such as component managers, effective systems, skilled knowledge workers and strong brands loyal customers). Robust evidence shows that the firms whom spend more on intellectual capital have generated decent revenue and profit for their depositors and shareholders. These firms have outperformed their opponents on every financial measure. Referring to resource based theory, the effective and efficient use of human capital will drive the company to a better financial performance (Musibah \& Alfattani, 2014). The issue of directors' pay has risen so ample debate is the perception that the amounts being paid are very huge and rising. This is reported in the many studies issued in the media, particularly those which focus the growing differential between executive pay and that of lesser employees (Toynbee \& Walker, 2009).

\section{Research Method}

This paper uncovers the information released in the annual report by financial institutions of 16 Islamic banking in Malaysia. The study is an investigation of annual report disclosures in the year 2014 to 2017. The study uses both disclosure indices and content analysis to measure the degree of disclosures about Shari'ah Committees' remuneration. The paper was also being done to ensure the remuneration disclosures are followed at all times as expected by Bank Negara Malaysia. 
INTERNATIONAL JOURNAL OF ACADEMIC RESEARCH IN BUSINESS AND SOCIAL SCIENCES

Vol. 8, No. 11, Nov, 2018, E-ISSN: 2222-6990 @ 2018 HRMARS

Table 1. List of Licensed Financial Institutions in Malaysia

\begin{tabular}{|c|l|c|}
\hline No & Name & Ownership* \\
\hline 1 & Affin Islamic Bank Berhad & $\mathrm{L}$ \\
\hline 2 & $\begin{array}{l}\text { Al Rajhi Banking \& Investment Corporation(Malaysia) } \\
\text { Berhad }\end{array}$ & $\mathrm{F}$ \\
\hline 3 & Alliance Islamic Bank Berhad & $\mathrm{L}$ \\
\hline 4 & AmBank Islamic Berhad & $\mathrm{L}$ \\
\hline 5 & Bank Islam Malaysia Berhad & $\mathrm{L}$ \\
\hline 6 & Bank Muamalat Malaysia Berhad & $\mathrm{L}$ \\
\hline 7 & CIMB Islamic Bank Berhad & $\mathrm{L}$ \\
\hline 8 & HSBC Amanah Malaysia Berhad & $\mathrm{F}$ \\
\hline 9 & Hong Leong Islamic Bank Berhad & $\mathrm{L}$ \\
\hline 10 & Kuwait Finance House (Malaysia) Berhad & $\mathrm{F}$ \\
\hline 11 & MBSB Bank Berhad & $\mathrm{L}$ \\
\hline 12 & Maybank Islamic Berhad & $\mathrm{L}$ \\
\hline 13 & OCBC Al-Amin Bank Berhad & $\mathrm{F}$ \\
\hline 14 & Public Islamic Bank Berhad & $\mathrm{L}$ \\
\hline 15 & RHB Islamic Bank Berhad & $\mathrm{L}$ \\
\hline 16 & Standard Chartered Saadiq Berhad & $\mathrm{F}$ \\
\hline
\end{tabular}

\section{Research limitations/implications}

The paper depends on Islamic banks' disclosure of remuneration practices issued by the financial institutions in the annual reports of Islamic banks in Malaysia. In future research, interviews can be piloted with others such as remuneration boards, shareholders and Sharicah Committees to give a better picture of the remuneration disclosure practices conducted by these Islamic banks. This paper is then developed into concrete research hypotheses for future studies. Most of the Sharicah Committee is involved in administrative roles at their institutions or universities (Hasan, 2007). The implications of excessive pay to the Sharicah Committees would be the issue of the committee being paid by their institutions as well as them also receiving compensation from the bank. Hence, the company or financial institutions should disclose their remuneration to avoid negative perception towards their credibility and it also will increase the public's confidence. The effectiveness of the Sharicah Committees also can bring Islamic finance to a new level. The effectiveness of Sharicah governance in Islamic finance in Malaysia has been improved when the Malaysia government has introduced a special High Court in the Commercial Division or the muamalat bench and also the amendment of section 16B of the Central Bank of Malaysia Act, CBA 2003. The mu'āmalat bench in the High Court emphasised by the respective judges on the disputes on Islamic finance system and it also can be considered as an approach of coordinating the Islamic law and conventional law in Malaysia (Hasan, 2007; Ruzian Markom \& Norilawati Ismail, 2009)(Hasan, 2007; Ruzian Markom \& Norilawati Ismail, 2009). Sharicah governance is a soul to Islamic banking system of financial ecosystem and it can be considered as essence of corporate governance for Islamic banks. 


\section{Conclusion}

The study might focus the disclosure of Sharicah Committees' remuneration as reported by the financial institutions in the annual reports of Islamic banks in Malaysia. Ultimately, this study offers and formulates some recommendations for the purpose of enhancing and improving the present Sharicah committees' remuneration disclosure and Sharicah governance in Islamic banks. Hence, for future research, we aim to understand the effect of Sharicah Committees' remuneration towards Sharicah committee effectiveness. In order to achieve a good governance practice, the company should spend more financial resources on the Sharicah committees as a long-term investment in order to get a higher confidence level from the depositors or shareholder particularly. Appropriate remuneration should be provided to Sharicah committees to attend trainings, conferences, meetings and forums across the globe as a medium for them to be exposed to market developments and issues in the industry. Despite Bank Negara Malaysia's expectation that Sharicah committees has to ensure compliance with Islamic rules at all times, they still had to rely on moral persuasion which is inadequate to ensure compliance as lined up by central bank. Without reinforcement, the task of the Sharicah committees and the reports will continue to be highly motivated by the need to align with BNM guidelines. New blueprints will enhance the role of Sharicah committees and improve the governance aspect of the Sharicah committee decision making. Previous studies identified more governmental regulatory intervention is growing and has increased public confidence in companies (Adegbite, Shrives, \& Nichol, 2011). Much has been accomplished, but much still needs to be done.

\section{Acknowledgement}

I am highly indebted to Islamic Science University of Malaysia (USIM) and Ministry of Education Malaysia (MOE), for their support as well as providing scholarship for me. My thanks and appreciation also go to my colleagues and lecturers at IIUM Institute of Islamic Banking and Finance (IliBF).

\section{Corresponding Author}

Syahiru Shafiai

PhD Candidate

International Islamic University Malaysia (IIUM)

Institute of Islamic Banking and Finance

IIUM Gombak Campus, Kuala Lumpur Malaysia

Email: syahiru.shafiai@live.iium.edu.my

\section{References}

Adegbite, E., Shrives, P., \& Nichol, T. (2011). The Role of Government in Corporate Governance: Perspectives from the UK, 9(1), 283-293.

Ahmed, M. U. (2015). Financial reporting of Islamic financial institutions: The rationale, the present, and the future. Islamic Finance News. Retrieved from https://www.islamicfinancenews.com/ifn_authors/mezbah-uddin-ahmed

Ainley, M., Mashayekhi, A., Hicks, R., Rahman, A., \& Ravalia, A. (2007). Financial Services Authority Islamic Finance in the UK: Regulation and Challenges.

Alnasser, S. A. S., \& Muhammed, J. (2012). Introduction to corporate governance from Islamic 
INTERNATIONAL JOURNAL OF ACADEMIC RESEARCH IN BUSINESS AND SOCIAL SCIENCES

Vol. 8, No. 11, Nov, 2018, E-ISSN: 2222-6990 @ 2018 HRMARS

perspective. Humanomics, 28(3), 220-231.

Bakar, D. M. D. (2016). Shariah Minds in Islamic Finance (First Edit). Kuala Lumpur: Amanie Media Sdn. Bhd.

Baker, G. P., Jensen, M. C., \& Murphy, K. J. (1988). Compensation and Incentives: Practice vs . Theory. The Journal of Finance, XLIII(3), 593-616.

BCBS41. Basle Committee on Banking Supervision : Enhancing Bank Transparency, Basel Committee on Banking Supervision (1998). Bank For International Settlements.

BCBSD309. Basel Committee on Banking Supervision (Standard) - Revised Pillar 3 disclosure requirements, Basel Committee on Banking Supervision (2015). Bank For International Settlements.

BCBSD400. Pillar 3 disclosure requirements - consolidated and enhanced framework, Basel Committee on Banking Supervision (2017). Bank For International Settlements.

BNM. (2018). List of Licensed Financial Institutions in Malaysia, Bank Negara Malaysia. Retrieved June 10, 2018, from www.bnm.gov.my

BNM-FRIBI. Financial Reporting for Islamic Banking Institutions (2013). Bank Negara Malaysia.

BNM-GP8-i. Guidelines on Financial Reporting for Islamic Banking Institutions, Pub. L. No.

BNM/RH/GL/008-18 (2012). Malaysia: Bank Negara Malaysia.

BNM-SGF. Shariah Governance Framework for Islamic Financial Institutions 2011, Pub. L. No. BNM/RH/GL_012_3 (2010). Malaysia: Bank Negara Malaysia.

Deloitte. (2016). Second time around - Renewing your remuneration policy. Deloitte LLP, (March).

Elfeky, M. I. (2017). The extent of voluntary disclosure and its determinants in emerging markets:

Evidence from Egypt. The Journal of Finance and Data Science, 3(1-4), 45-59.

EY. (2015). World Islamic Banking Competitiveness Report 2016 (New realities, New opportunities). EY Marketing Business.

Faulkender, M., Kadyrzhanova, D., Prabhala, N., \& Senbet, L. (2010). Executive Compensation: An Overview of Research on Corporate Practices and Proposed Reforms. Journal of Applied Corporate Finance, 22(1), 107-118.

GIFR. (2017). Global Islamic Finance Report. Retrieved from http://www.gifr.net/publications/gifr2017/intro.pdf

Hanadzlah, A. H. (2012a). Malaysia as an Islamic financial hub. In Catalyzing for Change: A Financial Perspective (pp. 123-125). Kuala Lumpur: MPH Pubishing.

Hanadzlah, A. H. (2012b). Powering the heart of Malaysia: Islamic banking's new frontier. In Catalyzing for Change: A Financial Perspective (pp. 113-117). Kuala Lumpur: MPH Pubishing.

Harahap, S. S. (2002). The disclosure of Islamic values - Annual report: The analysis of Bank Muamalat's annual report. IQTISAD Journal of Islamic Economics, 3(1), 35-45.

Hasan, Z. (2007). Shariah Governance in the Islamic Financial Institutions in Malaysia. In Global Conference on Business and Finance. Texas, United States of America: The Institute of Business and Finance Research.

Hasan, Z. (2011). A survey on Shari'ah governance practices in Malaysia, GCC countries and the UK. International Journal of Islamic and Middle Eastern Finance and Management, 4(1), 30-51.

Idowu, S. O., Capaldi, N., Zu, L., \& Gupta, A. Das. (2013). Encyclopedia of Corporate Social Responsibility. London: Springer-Verlag Berlin Heidelberg. 
INTERNATIONAL JOURNAL OF ACADEMIC RESEARCH IN BUSINESS AND SOCIAL SCIENCES

Vol. 8, No. 11, Nov, 2018, E-ISSN: 2222-6990 @ 2018 HRMARS

IIRC. (2013). The International Integrated Reporting Framework. Integrated Reporting (IR).

Insights. (2014). Shariah Compliance in All Matters. The Priority of a Robust Islamic Finance

Ecosystem. Centre, Malaysia International Islamic Financial, Bank Negara Malaysia, (February), $1-7$.

Jaafar, A., \& El-Shawa, M. (2009). Ownership concentration, board characteristics and performance: evidence from Jordan. Research in Accounting in Emerging Economies (Vol. 9). Elsevier.

Jensen, M. C., \& Murphy, K. J. (1998). CEO Incentives - It's Not How Much You Pay, But How CEO. Harvard Business Review, Foundations of Organizational Strategy, Harvard University Press, 3(May-June 1990), 138-153.

Jizi, M. I., \& Dixon, R. (2017). Are Risk Management Disclosures Informative or Tautological? Evidence from the U.S. Banking Sector. Accounting Perspectives, 16(1), 7-30.

Kasim, N. A. A. (2012). Disclosure of Shariah compliance by Malaysian takaful companies. Journal of Islamic Accounting and Business Research, 3(1), 20-38.

Musibah, A. S., \& Alfattani, W. S. B. W. Y. (2014). The mediating effect of financial performance on the relationship between shariah supervisory board effectiveness, intellectual capital and corporate social responsibility, of islamic banks in gulf cooperation council countries. Asian Social Science, 10(17), 139-164.

Ray Proctor. (2006). Managerial Accounting for Business Decisions (Third Edition). Prentice Hall Financial Times.

Ruzian Markom, \& Norilawati Ismail. (2009). The Development Of Islamic Banking Laws In Malaysia: An Overview. Jurnal Undang-Undang, 13, 191-205.

Shabbir, M. (1999). Adequacy of Disclosure in Islamic Financial Institutions. Retrieved March 11, 2017, from http://www.islamic-banking.com/iarticle_5.aspx

Southam, C., \& Sapp, S. (2010). Compensation across executive labor markets: What can we learn from cross-listed firms. Journal of International Business Studies, 41(1), 70-87.

Suchman, M. C. (1995). Managing Legitimacy: Strategic and Institutional Approaches. Academy of Management Review, 20(3), 571-610. Retrieved from http://amr.aom.org/cgi/

Toynbee, P., \& Walker, D. (2009). Unjust Reward. Granta Books. 